\title{
IMPLEMENTATION OF LRD (LISTEN, READ, DISCUSS) STRATEGY LEARNING FOR INCREASING READING SKILL AND STUDENT ACHIEVEMENT ON DISCUSSION TEXT MATERIAL IN CLASS XII IIK 3 MADRASAH ALIYAH NEGERI 1 BANJARMASIN ACADEMIC YEAR 2019/2020
}

\author{
Mariani \\ Madrasah Aliyah Negeri 1 Banjarmasin \\ e-mail: mariani.man1bjm@gmail.com
}

\begin{abstract}
Has done research with the aim to increasing reading skill and student achievement on discussion text material through implementation of LRD strategy. This research design was used classroom action research which consisted two cycles with four phases; planning, action, evaluation and reflection. The subject were 37 students of class XII IIK-3 MAN 1 Banjarmasin. Data collection was used by test technique. Then, data were analyzed by quantitatively and qualitatively techniques. The research result showed that there was an increase in teacher's activity from 31 at cycle I to 41 at cycle II, an increase in student's activity from 23,50 at cycle I to 33 at cycle II, an increase in student's achievement from 64,86 at cycle I to 83,91 at cycle II, an increase in student's reading skill from 12,23 at cycle I to 15,73 at cycle II and student give good respon for learning which using LRD strategy.

Keyword : strategy learning, listen read discuss, student activity, teacher activity student achievement, reading skill, discussion text.
\end{abstract}

\section{INTRODUCTION}

Language cannot be separated from human life. Humans use language as a communication tool in their lives. With language, someone can convey ideas, thoughts, feelings, or information to others both verbally and in writing. It is in line with what Iskandarwassid and Dadang (2008) said that a language is a communication tool between community members in the form of sound symbols produced by human speech tools.

There are so many languages in the world, but English is defined as an international language, which means English is the language used by people throughout the world for communicating. Therefore, in Indonesia, English is used as one of the subjects taught to students in schools.

As a subject in a school, English is taught with four basic skills, namely reading, speaking, listening, and writing. In the learning process, reading and writing skills are more emphasized to be taught by students than by speaking and speaking skills. It is because students use English just for their academic needs.

Reading (reading) is one of the reasonably complex ways when we learn English. In reading activities, students are required to understand the ideas/information they want to be conveyed by the author. It is consistent with $\mathrm{Wu}$ and $\mathrm{Hu}$ (2017), reading is the most important basic skill. However, it is not easy to master reading skills (reading) since many factors affect a person in mastering reading skills. Furthermore, $\mathrm{Wu}$ and $\mathrm{Hu}$ (2017), two main factors influence reading skills, namely schema and vocabulary. Also, the other main factor is motivation.

Having good reading skills is very important for our lives, even for young students. At the elementary level, elementary school students and even kindergarten students learn English for the 
first time. Their teacher teaches them about the structure of English and vocabulary that is often used in daily life. The teacher should explain patiently because students at the elementary level are students who are active and like to move. They are easily attracted to something new. They are free and like fun things.

The important thing is that the teacher must explain English material as simple as possible so that students can receive the essence of the learning and clear explanation. The teacher must try to show that reading is a fun activity by providing varied material, topics, and genres. Teaching reading to teenagers, like students in high school, must be different from students at the elementary level because of the differences in their nature and characteristics. Also, reading activities, not only cognitive activities but must support the development of their psychology.

Based on the pre-test were conducted, in which the author conducted a test to test students' skills in reading. In this test, a dialog text is given about global warming. Each student in pairs was asked to read the dialogue text, and they must understand the contents of the text. In fact, they have no difficulty when reading the text. However, most students can answer the questions given by the author about the text they were read. Among all students, only 13 people scored above 75 . Then based on student data in Semester 2 of the Academic Year 2019/2020, the average student score was 55.19, with a percentage of completeness of $43.44 \%$.

From the obtained data, it can be said that student learning outcomes and reading skills in English subjects are still relatively low. The low learning outcomes and students' reading skills are influenced by several factors including: (1) students still have inefficient reading habits where they read English text word for word, (2) the students lack in mastering vocabulary, (3) very dependent on the dictionary or translator application and (4) the inappropriate teaching technique used by the teacher the in class.

Respond to the problems, the teacher's role as an educator is needed to be creative and innovative to find solutions in improving the quality of learning, in terms of student learning outcomes and reading skills. One of the techniques for improving reading skills and student learning outcomes is the use of LRD (Listen, Read, Discuss) strategies.

LRD is one of the strategies used by teachers in English language learning in the classroom. This strategy helps students to improve their reading skills and learning outcomes. By implementing this strategy, learning becomes more active, meaningful, and efficient. It is supported by research conducted by Manzo (2018), where the use of LRD strategies can improve student reading skills.

\section{RESEARCH METHOD}

This research was designed and conducted using Classroom Action Research (CAR). According to Kunandar (2013), CAR is a form of self-reflection activities carried out by education practitioners in educational situations to improve rationality and fairness about (a) their educational practices, (b) their understanding about the practices, and (c) the situation in which the practices are carried out.

The study was conducted in August 2019 until September 2019. it is conducted in class XII IIK-3 MAN 1 Banjarmasin. The research subjects were XII IIK-3 class MAN 1 Banjarmasin totaled 37 people consisting of 18 women and 19 men, while the objects in this study were teacher activities, student activities, student learning outcomes, 
student reading skills and student responses to teaching and learning

The data about cognitive learning outcomes were collected through written tests consisting of 20 multiple choice questions at every the end of the cycle. Just like cognitive learning outcomes, data about students' reading skills are collected through written tests in the form of 5 breakdown questions that were also given at the end of each cycle. Then, the data of teacher activities, student activities, and affective learning outcomes were collected through non-tests, namely observation sheets at each meeting, and student responses were collected through student questionnaire at the end of cycle II.

The assessment of observational aspects in the observation sheet of the teacher activity uses a score of 1-5 with an assessment rubric that measures 15 items of teacher activity. The categories for teacher activities can be seen in Table 1 .

Table 1. Categories of Teacher Activity

\begin{tabular}{cc}
\hline Score Range & Categories \\
\hline $10-18$ & Tidak baik \\
\hline $19-26$ & Kurang baik \\
\hline $27-34$ & Cukup baik \\
\hline $35-42$ & Baik \\
\hline $43-50$ & Sangat baik \\
\hline & Adapted Sudjana (2014)
\end{tabular}

The assessment of the observational aspects in the observation sheet of student activity uses a score of 1-5 accompanied by an assessment rubric that measures 12 student activities. The categories for student activities can be seen in Table 2

Table 2. Categories of Student Activity

\begin{tabular}{cc}
\hline Score Range & Categories \\
\hline $8-15$ & Tidak aktif \\
\hline $16-21$ & Kurang aktif \\
\hline $22-27$ & Cukup aktif \\
\hline $28-33$ & Aktif \\
\hline $34-40$ & Sangat aktif \\
\hline & Adapted (Sudjana, 2014)
\end{tabular}

Analysis of cognitive student learning outcomes aims to determine the level of mastery of student concepts. Based on MAN 3 Banjarmasin Mastery Learning Criteria (KKM), students who score more or equal to 75 are indicated complete learning. The success of students in mastering English subjects is shown by the average value of students as a whole, 75 , absorption $\geq 75$, and mastery learning $\geq 75$. To describe the success of students in learning can be seen in Table 3.

Table 3. Categories Cognitive Student Learning Outcomes

\begin{tabular}{cc}
\hline Score Range & Categories \\
\hline $\mathrm{x}<65$ & Sangat Rendah \\
\hline $65 \leq \mathrm{x}<75$ & Rendah \\
\hline $75 \leq \mathrm{x}<85$ & Cukup \\
\hline $85 \leq \mathrm{x}<95$ & Baik \\
\hline $\mathrm{x} \geq 95$ & Sangat Baik \\
\hline & Adapted (Sudijono, 2010)
\end{tabular}

The assessment of observational aspects in the observation sheet about affective learning outcomes of students uses a score of 1-5 that measures 4 affective aspects, namely honest, disciplined, responsible, and confident. The categories for affective learning outcomes of students can be seen in Table 4.

Table 4. Categories affective learning outcomes

\begin{tabular}{cc}
\hline Score Range & Categories \\
\hline $0-3$ & Sangat kurang \\
\hline $4-7$ & Kurang \\
\hline $8-10$ & Cukup \\
\hline $11-13$ & Baik \\
\hline $14-16$ & Sangat baik \\
\hline & Adapted (Sudjana, 2014)
\end{tabular}

The assessment of students' reading skills uses a written test with 5 essay questions. The categories of students' reading skills can be seen in Table 5 . 
Table 5. Categories of Students' Reading Skills

\begin{tabular}{cc}
\hline Score Range & Categories \\
\hline $5-8$ & Sangat Kurang \\
\hline $9-11$ & Kurang \\
\hline $12-14$ & Cukup \\
\hline $15-17$ & Baik \\
\hline $18-20$ & Sangat Baik \\
\hline
\end{tabular}

Then the assessment of students responses to learning English movie conducted with questionnaire using a Likert scale 1-5 containing 10 questions with answer choices strongly disagree (STS) $=1$, disagree $(\mathrm{TS})=2$, doubt $(\mathrm{RR}))=3$, agree $(\mathrm{S})=4$, and strongly agree $(\mathrm{SS})=5$. The categories of student responses can be seen in Table 6.

Table 6. Categories Students' Response

\begin{tabular}{cc}
\hline Average Score & Categories \\
\hline $10-18$ & Sangat kurang baik \\
\hline $19-26$ & Kurang \\
\hline $27-34$ & Cukup \\
\hline $35-42$ & Baik \\
\hline $43-50$ & Sangat positif \\
\hline & Adapted Widayoko (2014)
\end{tabular}

Indicators of this study are (1) teacher activity is indicated improve if it is at least classified in the good category, (2) student activity is indicated to be improved if it is at least classified in the good category, (3) student reading skills are indicated to be classified as good, (4) average average cognitive learning outcomes of students at least 75, completeness of learning $(\mathrm{KB})$ of at least $75 \%$ of the total number of existing students and absorptive capacity (DS) of at least $75 \%$, (5) affective learning outcomes of students in carrying out learning are indicated improve at least in good categories and (6) student responses are included in both categories.

\section{RESULTS AND DISCUSSIONS Results}

The results of the evaluation and observation of research in the first and second cycle in the form of teacher activities, student activities, student reading skills, student learning outcomes, and student responses to learning with English movie learning media. The increase of teacher activity scores in cycle II compared to cycle I can be seen in Figure 1.

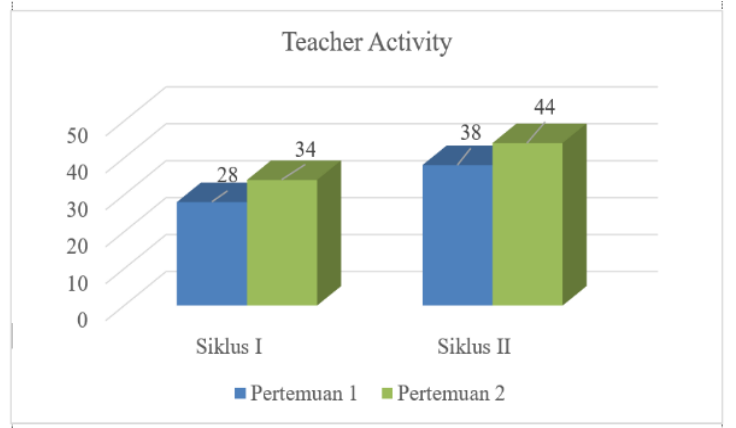

Figure 1. The Increase of Teacher Activity Scores in Each Meeting

The increase of student activity scores in cycle II compared to cycle I can be seen in Figure 2.

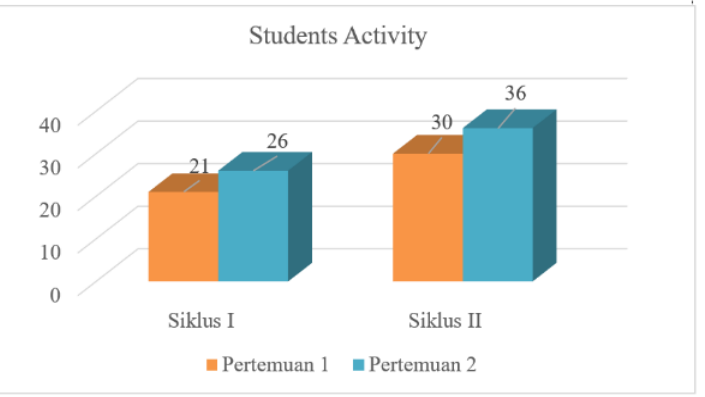

Figure 2. Increase of Student Activity Scores in Each Meeting

The Increase score of affective learning outcomes of students in the second cycle compared with the first cycle can be seen in Figure 3.

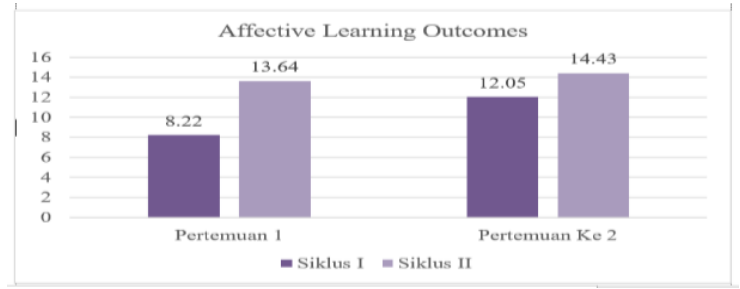

Figure 3. Increase Score of Affective Learning Outcomes of Students 
The improvement of cognitive learning outcomes data in this study was seen from 3 aspects, namely the average value of learning outcomes, absorption, and learning completeness. Following the increase in the average value of students' cognitive learning outcomes in cycle II compared with the cycle I can be seen in Figure 4.

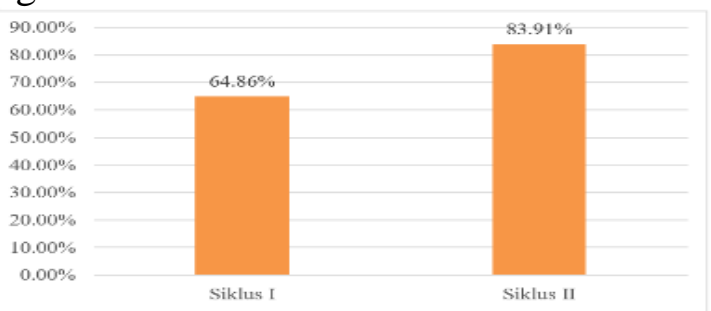

Figure 4. Improvement of Cognitive Learning Outcomes in Each Cycles

Then, the increased absorption and mastery learning in the second cycle when compared with the first cycle that can be seen in Figure 5

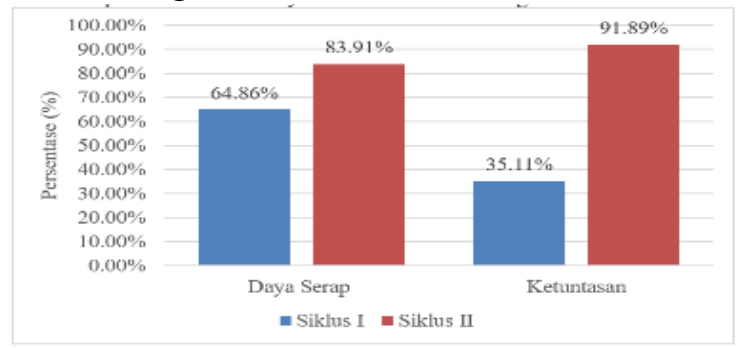

Figure 5. The Increased Absorption and Mastery Learning

The increased value of students reading skills in cycle II when compared to cycle I can be seen in Figure 6.

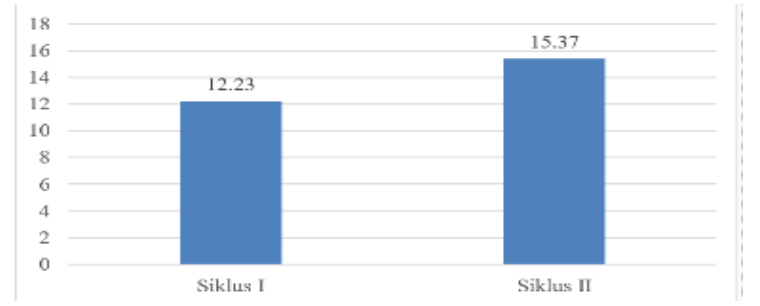

Figure 6. The Increased Value of Students' Reading Skills
The questionnaire was given to students after the second cycle. This questionnaire aims to determine the response of 37 students of class XII IIK-3 MAN 1 Banjarmasin to learning using the LRD strategy. The calculation results showed that $81.08 \%$ gave a good response to the use of LRD strategies in the learning process.

\section{Discussions}

This class action research was conducted using LRD learning strategies to improve reading skills and student learning outcomes. It is proven by an improvement of student learning outcomes and reading skills from cycle I to cycle II. Also, there was an improvement in teacher activity, student activity, and effective students in each meeting based on the assessment of observations did by 37 observers. This research was conducted in two cycles, with each cycle consisting of two meetings.

\section{Assessment analysis of teacher activity}

Overall the learning process in the first cycle has been going pretty well based on the teacher activity assessment sheet. Nevertheless, even though it is good enough, there is still some minus such as the teacher who is still lacking in providing overall guidance.

In the other hand, learning at this first meeting takes much time so that the whole learning phase cannot be carried out so that the teacher and students cannot conclude the learning material together. Accordance with Warsono and Hariyanto (2013) which states that the shortcomings in implementing learning with media are often timeconsuming.

Moreover, the score of teacher activity at this first meeting was 28 , and it indicated as a quite good category. In order to conduct the next learning process, the observers provide input so that the teacher is more creative in encouraging students to ask 
questions. Additionally, in managing time, the teacher should be able to manage time well so that the learning steps can be implemented well.

At the second meeting of the first cycle, all suggestions and input provided by the observer were implemented by the teacher so that an increase in the teacher's activity score to 34 was quite good. The teacher is good enough in all aspects of teacher activities in carrying out learning, such as encouraging students to ask questions, condition students to ask questions, give direction to students to discuss, and so forth. Overall, the score of the teacher's activity, even though it is in a quite good category, but the score does not meet the standard score of the teacher's activity expected by the teacher as the writer. Therefore, the assessment of teacher activity in cycle I was used as a reflective material in cycle II. The assessment of teacher activity is continued to cycle II.

In the second cycle, the teacher is more capable of managing the class and managing time so that the learning steps that have been planned can be implemented well. Also, teachers are more capable of making the learning process more fun and meaningful as a result, students become more motivated in learning. According to the opinion of Roberto (2015) that a fun and dynamic teaching and learning process can increase learning challenges for students so that student learning outcomes are improved.

Teacher activity in each cycle II continues to improve. In the second cycle at the first meeting, the teacher activity score was 38 in a good category and increased in the second meeting in cycle II to be 44 with the same category. Compared to cycle I, the teacher's activity score increased by 10 points from 31 with a good enough category, then increasing to 41 with a good category in cycle II.

\section{Assessment analysis of student activity}

Based on observations, the students' activity at the first meeting of the first cycle showed quite good with a score of 21 . However, even though quite good, some things need to be improved. The thing that needs to be improved is that there are still some students having difficulty understanding the meaning of the text/article being read. It was due to limited vocabulary. Moreover, students are still relatively passive, especially when the teacher gives directions to them to ask questions and discuss.

For a good implementation of the learning process at the next meeting, the observers provide advice and input. Based on the advice given, the teacher tries to be more creative in building the learning process that can transfer material from the teacher to students properly. The improvement effort made by the teacher gives an influence on student activities, which is an increase in scores at the second meeting by 5 points from 21 at the first meeting to 26 at the second meeting. Overall, student activity in the first cycle was quite good, with an average score of 23, but the average score obtained in the first cycle did not meet the standard student activity scores that expected by the teacher as the writer. Therefore, the assessment of student activities in cycle I was used as reflection material in cycle II. The assessment of teacher activity is continued to cycle II.

By observing the results of the observation of student activities in cycle I, the implementation of learning in cycle II is further enhanced by correcting deficiencies during the learning process of cycle I. The things that are not optimal in the teacher's 
activities are also improved so that they are expected to have an impact on increasing student activity.

Overall from the first stage, the middle and final learning activities of students are classified as good. Students look more motivated in learning. Students begin to discuss with the group actively, students are also seen to be active in asking questions when they have difficulty, or there is material that they do not understand. It happens cause students are getting used to the learning patterns implemented by the teacher. In addition, an increase in student activity scores occurred because students are more motivated to participate in learning by using the LRD strategy. When students are motivated, students will become active in learning activities.

If seen in each cycle, student activity from cycle I to cycle II has increased wherein the first cycles the average score of 23.50 with a good enough category increased in cycle II to 33 with the active category. It is per the results of Ariyanti's research (2015), which states that using the LRD strategy can increase the average percentage of student activity by $74.40 \%$ at the end of cycle II. Likewise, Pratiwi's study (2015) using LRD strategies of $76.25 \%$ of students had high learning activities.

\section{Assessment analysis of student reading skills}

Overall, student reading skills in the first cycle and second cycle increased from an average score of 12.23 in the first cycle to 15.73 in the second cycle with a good category. Improvement occurred because the use of the LRD strategy can build student reading skills. According to Manzo and Casela (2008) that the use of LRD strategies can increase students' fundamental knowledge before they read the given text.
Also, several other advantages are, namely (1) increasing students 'understanding of reading comprehension, (2) enriching students' vocabulary, and (3) training students to understand the correct structure and rules about the use of the language being taught. It is in line with Jayanti's research (2016), which states that there are significant differences in the reading skills of students who learn with LRD learning strategies and students who do not go through learning with LRD learning strategies.

\section{Assessment analysis Test of Student Cognitive Learning Outcomes}

After the learning process in the first cycle is completed, then at the end of the cycle, a cognitive learning achievement test is performed to determine the students' skills in absorbing the material that has been discussed. Based on the results of the study, the average value, absorption, and completeness of learning increased from cycle I to cycle II, where the average value increased by 19.05 from 64.86 in cycle I to 83.91 in cycle II. Then the absorption has increased by $19.05 \%$ from $64.86 \%$ in the first cycle to $83.91 \%$ in the second cycle, and mastery learning has increased by $56.71 \%$ from $35.11 \%$ in the first cycle to $80.52 \%$ in cycle II.

The implementation of the LRD learning strategy makes students look more active and happy in following the learning process. An active and happy learning process makes the knowledge gained meaningfully and makes it easier for students to understand the subject matter delivered by the teacher. As a result, student learning outcomes improve. It is per with Irma's research (2015) which states that using LRD learning strategies in the learning process can produce an increase in student achievement in learning. Likewise, Nita's 
research (2018) concludes that the LRD strategy can make student learning outcomes complete classically.

\section{Assessment Analysis of Student Affective Learning Outcomes}

Aside from cognitive learning outcomes, this study also assessed learning outcomes of students' affective aspects. The affective aspects of students assessed in this study are honest, confident, disciplined, and responsible. The affective aspects of students are assessed in each learning process using an observation sheet that has been accompanied by an assessment rubric.

Overall the Affective learning outcomes of students in the first cycle are 10,13 with a pretty good category. Because the obtained result is still not incompatible with the desired target, then further learning is held in the second cycle. In cycle II, improvements were made so that there was an increase in the affective aspects to 14.01 with good categories.

It can be said that the LRD learning strategy has a positive influence on students' affective learning outcomes. In line with Nita's research (2018) which states that an increase in the attitudes of students shows that through the learning process with the LRD strategy can cause students to have enthusiasm and motivation towards the learning process; as a result, the attitudes expected of students can arise in the process learning.

\section{Analysis of Student Responses toward Learning}

Based on the results of the assessment of students' responses toward learning using the LRD learning strategy, most students gave good responses. Good responses given by students are shown by the number of students who gave very good and good responses compared to adequate, not good, and very bad responses.

The student's good response indicates that learning using the LRD learning strategy makes students more interested and motivated to participate in learning and makes it easier for students to understand the material being taught.

\section{CONCLUSION}

Based on the discussion above, this research has answered the existing action hypothesis that the use of LRD learning strategies has succeeded in improving the learning process so that it can improve students' reading skills and student learning outcomes (cognitive and affective) in cycle I and cycle II. In addition, students also show a good response to learning by using LRD learning strategies. With the application of LRD as a learning process, students find it easier to understand and better understand the English spoken. Students can answer the questions in students' reading skills tests and learning outcomes more efficiently, and also the learning process can be carried out with more fun and meaningful.

\section{REFERENCES}

Ariyanti, P. (2015). Penerapan Strategi LRD untuk Meningkatkan Keaktifan dan Hasil Belajar Pada Mata Pelajaran Bahasa Inggris Di SMA Negeri 2 Surakarta Tahun Ajaran 2014/2015. Jurnal Pendidikan UNS. 4(1): 1-8.

Irma. (2015). Penerapan Strategi LRD untuk Meningkatkan Hasil Belajar Bahasa Indonesia Kelas V. Jurnal PGSD. 12(1): 22-23.

Iskandarwassid dan Dadang Suwendar. (2008). Strategi Pembelajaran Bahasa. $\quad$ Bandung: Remaja Rosdakarya. 
Jayanti. (2016). The Use of Listen-ReadDiscuss (L-D-R) Strategy to Improve reading Comprehension (Classroom Action Research of the Eighth Grade Students of SMP N 3 Salatiga in the Academic Year of 2015/2016. Graduating Paper STAIN Salatiga. 4(3): 89-90.

Kunandar. (2013). Penilaian Autentik (Penilaian Hasil Belajar Peserta Didik Berdasarkan Kurikulum 2013). Jakarta: Rajawali Press.

Manzo dan Rasinki, T.V. 2015. ListenRead-Discuss: A Content Reading Heuristic. Journal of Reading. 2(8): 732-734.

Manzo, A.,V \& Casela, U. P. (2008). Teaching Children to be Literate: A Reflective Approach. New York: Holt, Rinehart and Winston, Inc.

Nita, R. (2018). Keefektifan Strategi LRD Dalam Pembelajaran Membaca Pemahaman dan Hasil Belajar SIswa pada Siswa Kelas XI SMA Negeri 1 Tempel Yogyakarta. Journal of Education. 7(2): 90.

Pratiwi, Y. (2015). Pelaksanaan Strategi Listen, Read dan Discuss di Kelas X SMA Negeri 5 Surakarta Tahun Pelajaran 2014/2015. Jurnal Pendidikan UNS. 3(2): 50-58.

Purwanto. (2013). Evaluasi Hasil Belajar. Jakarta: Pustaka Pelajar.

Reniwati, P. (2017). The Effect of Using LRD (Listen, Read, Discuss) Strategy toward Reading Comprehension of the Second Year Students at State Junior High School 9 Tapung Kampar Regency. Journal Paper of UIN Riau. 9(2): 45-59.

Roberto, L. C. R. (2015). The Pros and Cons of Learning from the Teacher's Standpoint. Journal of University Teaching \& Learning Practice. 3(1) : 1-19.
Sudaryono. (2012). Dasar-Dasar Evaluasi Pembelajaran. Yogyakarta: Graha Ilmu.

Sudjana, N. (2014). Penilaian Hasil Proses Belajar Mengajar. Bandung: Remaja Rosdakarya.

Sudijono, A. (2014). Pengantar Statistik Pendidikan. Jakarta: Rajawali Pers.

Suharsimi, dkk. (2012). Penelitian Tindakan Kelas. Jakarta: Bumi Aksara.

Wu, H.,Y dan Hu, Ping. (2017). Major Factors Influencing Reading Comprehension. Sino-Us English Teaching Journal. 4(9): 14-19. 